\title{
Hubungan Klasifikasi Perokok dengan Kesehatan Jaringan Periodontal Masyarakat yang Merokok di Pulau Harapan diukur dengan Skor CIPTN
}

\author{
Baby Prabowo ${ }^{1, *}$, Triyawati Rosida ${ }^{2}$, Hidayati Ahmad ${ }^{3}$ \\ ${ }^{1}$ Akademi Kesehatan Gigi Puskesad, Senen, Jakarta Pusat 10410, Indonesia \\ ${ }^{1}$ Email: baby.prabowo@akgpuskesad.ac.id*; ${ }^{2}$ Email: triyawati14@ gmail.com, ${ }^{3}$ Email: hida.ahmad@akgpuskesad.ac.id \\ * corresponding author
}

ARTICLE INFO

Keywords

Periodontal

Jaringan

Perokok

Gigi

Kesgilut

\section{ABSTRACT}

The Ministry of Health in Alamsyah, (2017) states that smoking behavior is an activity of burning one of the tobacco products, then smoking or inhaling the smoke, including clove cigarettes, white cigarettes, cigars or other forms produced from the nicotina tabacum, nicotina rustica and other species. The classification of smokers consists of: light smokers (1-4 cigarettes/day), moderate smokers (5-14 cigarettes/day), heavy smokers (> 15 cigarettes/day). This study was conducted to obtain an overview of the health of the periodontal tissue in people who smoke on the island of Harapan. Data were collected by classifying smokers and intra-oral examination of CPITN on every community who smoked on the island of Harapan whose results were recorded on the examination sheet. This examination was carried out in January 2020. The data were analyzed by Univariate and Bivariate. Based on the results of research on male smokers in Harapan Island, Seribu Islands region, it can be concluded that there are no smokers who have a score of 0 or have healthy periodontal tissue. In the category of moderate smokers, the highest number of CIPTN 2 scores or had tartar on the sub gingiva was 9 people $(52.9 \%)$, while in the heavy smoker group the highest score also had CIPTN 2 scores or had tartar on the sub gingiva as many as 18 people $(48,6 \%)$. The statistical test results obtained $\mathrm{P}=0.029$ where the $\mathrm{P}$ value $<0.05$, it can be concluded that there is a difference in the proportion of the classification of smokers to the state of the periodontal tissue calculated based on the CIPTN status or there is a significant relationship between the classification of smokers and the state of the periodontal tissue calculated by the CIPTN score).

\section{Pendahuluan}

Menurut Sumerti (2016), rokok telah menjadi kebiasaan bagi kehidupan, rokok merupakan masalah bagi kesehatan masyarakat di dunia, sekitar tiga juta manusia di dunia meninggal akibat rokok. Zat adiktif pada rokok dapat menimbulkan berbagai macam penyakit, seperti penyakit jantung, pembuluh darah, stroke, penyakit paru obstruktif kronik, kanker paru, juga dapat menyebabkan timbulnya kondisi patologis di dalam rongga mulut.

Presentase penduduk dunia yang menghisap tembakau sebesar 57\% pada penduduk Australia dan Asia, 14\% pada penduduk Eropa Timur dan pecahan Uni Soviet, 12\% penduduk Amerika, 9\% penduduk Eropa Barat dan 8\% pada penduduk Timur Tengah serta Afrika (WHO, 2015). Negara Indonesia memiliki jumlah perokok terbanyak dibandingkan dengan di Asia Tenggara sebesar $51,11 \%$. Tercatat sebanyak 57,6 juta orang perokok laki - laki dan 2,3 juta perokok wanita di Indonesia pada tahun 2011 (Nelis, dkk, 2015). Data Riskesdas (2018), menggambarkan prevalensi 
merokok pada penduduk Indonesia secara nasional persentase penduduk umur 10 tahun ke atas yang merokok setiap hari adalah $28,8 \%$. Persentase tertinggi ditemukan di Provinsi Jawa Barat dan Gorontalo 32\%, diikuti dengan Lampung, Bengkulu dan Banten 31,8\%. Sedangkan persentase terendah dijumpai di Provinsi Kalimantan Selatan, DIY dan Bali 23,5\%.

Gigi dan jaringan lunak rongga mulut merupakan bagian yang mengalami kerusakan akibat rokok, seperti kebersihan mulut, karies gigi, penyakit periodontal, memperlambat penyembuhan luka, lesi pre kanker, dan kanker mulut adalah kasus yang ditemukan pada perokok (Kusuma, 2012 dalam Sumerti, 2016). Kandungan rokok berupa tembakau, tar, nikotin, karbon monoksida, ammonia dapat mengiritasi rongga mulut saat dikonsumsi karena adanya pembakaran (Novitasari, dkk, 2014). Tembakau menjadi faktor yang beresiko signifikan untuk penyakit periodontal, yang dapat menyebabkan gusi menjadi surut (Hongini, 2012).

Kerusakan jaringan periodontal yang lebih parah pada kelompok perokok disebabkan adanya ketidakseimbangan antara serangan bakteri dan respon jaringan. Komposisi bakteri di dalam subgingiva mengalami pergeseran dengan bertambahnya jumlah dan virulensi mikroorganisme yang patogen. Jika kondisi ini disertai dengan berkurangnya respon jaringan terhadap serangan bakteri tersebut, hal ini yang memperparah kerusakan jaringan periodontal perokok (Putri, 2010).

Zat kimia dalam rokok dapat merusak jaringan gusi dengan cara mempengaruhi perlekatan antara tulang dan jaringan lunak ke gigi, pengaruh ini yang menyebabkan perokok lebih rentan terhadap infeksi seperti penyakit periodontal. Penyakit periodontal merupakan salah satu penyakit yang sangat banyak diderita manusia, masyarakat menganggap keadaan ini sebagai sesuatu yang biasa. Penyakit yang paling sering mengenai jaringan periodontal adalah gingivitis dan periodontitis (Fitri, 2010). Berdasarkan data dari Riskesdas dalam Tambunan, dkk, (2018), penyakit periodontal merupakan masalah kesehatan gigi dan mulut yang memiliki prevalensi cukup tinggi di masyarakat sebesar 95,58\%.

Penelitian sebelumya menunjukan bahwa lama waktu merokok menunjukkan bahwa proporsi pocket periodontal yang lebih dalam $>1,4 \mathrm{~mm}$ lebih banyak terjadi pada responden yang lama merokoknya mencapai $>17$ tahun $61,4 \%$ dibanding responden dengan lama merokok $\leq 17$ tahun $39 \%$. Merokok $>17$ tahun memiliki risiko 2.482 kali lebih besar memiliki pocket periodontal $>1,4$ $\mathrm{mm}$ dibanding yang merokok $\leq 17$ tahun. Penggunaan tembakau terbukti berpengaruh terhadap kekambuhan penyakit periodontal. Meningkatnya paparan tembakau dan jumlah rokok yang dihisap setiap hari, meningkatkan risiko periodontitis. Tembakau berkaitan dengan resesi gingiva dan kerusakan periodontal di lokasi gigi yang bersentuhan langsung dengan tembakau (Saptorini, 2013).

Jika tenaga kesehatan gigi secara rutin menganjurkan berhenti merokok pada pasien pasiennya diperkirakan antara 63.000 hingga 190.000 perokok akan berhenti merokok setiap tahunnya (Putri, 2015). Berdasarkan latar belakang di atas, peneliti ingin membuat penelitian yang berjudul "Hubungan Klasifikasi Perokok dengan Kesehatan Jaringan Periodontal Masyarakat yang Merokok di Pulau Harapan diukur dengan Skor CIPTN."

\section{Metode}

Penelitian yang digunakan dalam penelitian ini adalah penelitian deskriptif. Penelitian deskriptif adalah penelitian yang dilakukan untuk mendeskripsikan atau menggambarkan suatu fenomena yang terjadi di masyarakat (Notoatmodjo, 2018). Data yang didapatkan dalam penelitian ini setelah melakukan pemeriksaan gigi yaitu dengan cara melihat keadaan klinis gigi dan mulut pasien dengan teknik intra oral. Populasi yang digunakan dalam penelitian ini adalah pada perokok 
di Pulau Harapan. Teknik sampling yang digunakan yakni purposive sampling.

Menurut Notoatmodjo (2010), purposive sampling merupakan pengambilan sampel didasarkan pada suatu pertimbangan yang dibuat peneliti berdasarkan ciri atau sifat populasi yang sudah diketahui sebelumnya. Melakukan pengklasifikasian perokok dan dilakukan pemeriksaan intra oral CPITN pada gigi indeks. Sampel yang diteliti memiliki Kriteria Inklusi : Perokok ringan $1-4$ batang perhari, Perokok sedang 5 - 14 batang perhari, dan perokok berat lebih dari 15 batang perhari. Kriteria Eksklusi : Responden tidak bersedia untuk dilakukan pemeriksaan, Merokok hanya ingin mencoba, Merokok karena stres. Rumus besar sampel yang digunakan dalam penelitian ini ialah rumus Lameshow (1990) dengan jumlah sampel 49 orang, Upaya untuk mengantisipasi adanya drop out, sampel ditambah 10\%, maka besar sempel 54 orang.

Penelitian dilakukan di Bulan Januari 2020 di Pulau Harapan Kepulauan Seribu. Pada penelitian ini, data dianalisa dengan menggunakan analisis univariate (analisis deskriptif). Menurut Notoatmodjo (2010), analisis univariate bertujuan untuk menjelaskan atau mendeskripsikan karakter setiap variabel, bentuk data analisis univariate tergantung dari jenis datanya. Analisis Bivariate digunakan untuk menganalisis hubungan antara klasifikasi perilaku merokok dengan Keadaan jaringan periodontal dilihat dari skor CIPTN dengan menggunakan uji Chi Square.

\section{Hasil dan Diskusi}

\section{Analisis Univariat}

a. Umur

Distribusi Responden berdasarkan umur

\begin{tabular}{cccc}
\hline No & Umur & F & \% \\
\hline $\mathbf{1}$ & $17-25$ tahun & 6 & 11,1 \\
$\mathbf{2}$ & $26-35$ tahun & 24 & 44,4 \\
$\mathbf{3}$ & $35-45$ tahun & 24 & 44,4 \\
\hline & Total & 54 & 100
\end{tabular}

Berdasarkan data diatas dapat dilihat bahwa distribusi perilaku merokok masyarakat di Pulau Harapan paling banyak berada pada rentan usia 26 - 35 tahun sebanyak 24 orang ( 44,4\%), dan usia 35 - 45 tahun sebanyak 24 orang ( 44,4\%).

b. Perilaku merokok, yang merupakan Frekuensi merokok dalam sehari diklasifikasikan dalam 3 kategori : Perokok ringan merokok $1-4$ batang perhari, Perokok sedang merokok 5 - 14 batang perhari, Perokok berat merokok lebih dari 15 batang perhari.

Distribusi Responden berdasarkan Perilaku merokok

\begin{tabular}{cllcc}
\hline No & & Klasifikasi & F & $\%$ \\
\hline 1 & Ringan & & 0 & 0 \\
2 & Sedang & & 17 & 31,5 \\
3 & Berat & & 37 & 68,5 \\
\hline & & Total & 54 & 100 \\
\hline
\end{tabular}

Berdasarkan data diatas dapat dilihat bahwa klasifikasi perokok tertinggi termasuk dalam kategori berat yaitu sebanyak 37 responden $(68,5 \%)$. Sedangkat pada klasifikasi perokok sedang sebanyak 17 orang $(31,5 \%)$. Tidak ditemukan perokok dengan kategori ringan di Pulau Harapan 


\section{c. Jaringan Periodontal}

Distribusi Frekwensi Perilaku merokok berdasarkan Presentase Periontal Pocket

\begin{tabular}{clcc}
\hline No & \multicolumn{1}{c}{ Periodontal Pocket } & F & \% \\
\hline $\mathbf{1}$ & Skor 0, sehat & 0 & 0 \\
$\mathbf{2}$ & Skor 1, perdarahan pada gusi & 7 & 13 \\
$\mathbf{3}$ & Skor 2, karang gigi pada subgingiva & 27 & 50 \\
$\mathbf{4}$ & Skor 3, poket dangkal (3.5 $-5.5 \mathrm{~mm})$ & 18 & 33,3 \\
$\mathbf{5}$ & Skor 4, poket dalam (lebih dari 5.5 mm) & 2 & 3,7 \\
& & & \\
\hline & Total & 54 & 100 \\
\hline
\end{tabular}

Berdasarkan data diatas dapat dilihat bahwa keadaan jaringan periodontal yang dilihat berdasarkan skor CIPTN, terbanyak responden mengalami Karang gigi pada sub ginggiva sebanyak 27 responden (50\%), sedangkan terbanyak ke dua ialah dengan skor 3 yaitu dengan keadaan pocket dangkal sedalam 3,5 - 5,5 mm sebanyak 18 responden (33,3\%). Tidak ditemukan perokok dengan keadaan jaringan periodontal yang sehat.

\section{d. Hubungan Umur dengan klasifikasi perilaku merokok}

\begin{tabular}{llcccc}
\hline & Umur & \multicolumn{3}{c}{ Klasifikasi Perokok } & \\
& & Ringan & sedang & Berat & Total \\
\hline 1 & $17-25$ tahun & 0 & 3 & 3 & 6 \\
2 & \multirow{3}{*}{$26-35$ Tahun } & 0 & $50.0 \%$ & $50.0 \%$ & $100.0 \%$ \\
& & 0 & 7 & 17 & 24 \\
3 & $36-45$ tahun & 0 & $29.2 \%$ & $70.8 \%$ & $100.0 \%$ \\
& & 0 & 7 & 17 & 24 \\
\hline \multirow{2}{*}{ Total } & Count & 0 & $29.2 \%$ & $70.8 \%$ & $100.0 \%$ \\
& $\%$ within umur1 & 0 & 17 & 37 & 54 \\
& & 0 & $31.5 \%$ & $68.5 \%$ & $100.0 \%$ \\
\hline
\end{tabular}

Berdasarkan data diats dapat dilihat bahwa pada rentan usia perokok $17-25$ terdapat $50 \%$ perokok sedang dan 50\% perokok berat, sedangkan pada rentan usia 26 - 35 tahun perokok berat memiliki jumlah tertinggi dengan responden sebanyak 17 orang $(70,8 \%)$, dan pada usia 36 - 45 tahun tertinggi merupakan perokok berat sebanyak 17 responden $(68,5 \%)$. Berdasarkan ketiga kelompok umur perokok berat merupakan kelompok terbanyak dengan 37 responden $(68,5 \%)$.

e. Hubungan klasifikasi perilaku merokok dengan Keadaan jaringan periodontal dilihat dari skor CIPTN

\begin{tabular}{lcrrrrrr}
\hline No & $\begin{array}{c}\text { Klasifikasi } \\
\text { perokok }\end{array}$ & Sehat & $\begin{array}{c}\text { Perdarahan } \\
\text { pada Gusi }\end{array}$ & $\begin{array}{c}\text { Karang Gigi } \\
\text { pada Sub } \\
\text { gingiva }\end{array}$ & $\begin{array}{c}\text { Pocket } \\
\text { Dangkal }\end{array}$ & $\begin{array}{c}\text { Pocket } \\
\text { dalam }\end{array}$ & Total \\
\hline 1 & Ringan & 0 & 0 & 0 & 0 & 0 & 0 \\
\hline 2 & Sedang & 0 & 0 & 0 & 0 & 0 & 0 \\
\hline
\end{tabular}




\begin{tabular}{|c|c|c|c|c|c|c|c|}
\hline & & 0 & $29,4 \%$ & $52,9 \%$ & $11,8 \%$ & $5,9 \%$ & $100 \%$ \\
\hline \multirow[b]{2}{*}{3} & \multirow{2}{*}{ Berat } & 0 & 2 & 18 & 16 & 1 & 37 \\
\hline & & 0 & $5,4 \%$ & $48,6 \%$ & $43,2 \%$ & $2,7 \%$ & $100 \%$ \\
\hline & \multirow{2}{*}{ Total } & 0 & 7 & 27 & 18 & 2 & 54 \\
\hline & & 0 & $13,0 \%$ & $50,0 \%$ & $33,3 \%$ & $3,7 \%$ & $100 \%$ \\
\hline
\end{tabular}

Berdasarkan hasil analisis hubungan antara klasifikasi perilaku merokok dengan Keadaan jaringan periodontal dilihat dari skor CIPTN diperoleh data bahwa tidak terdapat perokok yang memiliki skor 0 atau memiliki jaringan periodontal sehat. Pada kategori perokok sedang paling banyak memiliki skor CIPTN 2 atau memiliki karang gigi pada sub gingiva sebanyak 9 orang (52,9\%), sedangkan pada kelompok perokok berat terbanyak juga memiliki skor CIPTN 2 atau memiliki karang gigi pada sub gingiva sebanyak 18 orang $(48,6 \%)$. Hasil uji statistik diperoleh $\mathrm{P}=0,029$ dimana nilai $\mathrm{P}<0,05$ maka dapat disimpulkan terdapat perbedaan proporsi klasifikasi perokok terhadap keadaan jaringan periodontal yang dihitung berdasarkan status CIPTN. (adanya hubungan signifikan antara klasifikasi perokok dengan keadaan jaringan periodontal yang dihitung dengan Skor CIPTN)

\section{Pembahasan}

Berdasarkan hasil penelitian didapatkan data sebagian besar perokok pria di pulau harapan berada pada rentang usia 26-35 tahun dan 35-45 tahun dengan jumlah responden sama yaitu masing masing 24 responden $(44,5 \%)$. pada usia 17 - 25 tahun hanya terdapat 6 responden $(11,1 \%)$, namun jika dijabarkan berdasarkan jumlah responden di masing masing tahun hasil berbeda akan terlihat dimana jumlah perokok tertinggi berda pada usia 25 tahun sebanyak 6 responden $(11,1 \%)$ di bandingkan usia lainnya, dari data tersebut dapat kita lihat bahwa tren perokok di Pulau Harapan dominasi oleh usia 25 tahun atau merupakan kategori remaja akhir. Diperlukan program pencegahan yang lebih berfokus pada rentan usia diatas, pendidikan kesehatan mengenai bahaya merokok dengan didukung regulasi lain yang terkait guna menghambat akses remaja kepada rokok dirasa dapat berhasil menanggulangi jumlah perokok baru pada usia ini.

Berdasarkan hasil penelitian juga didapatkan bahwa sebagian besar perokok merupakan perokok berat sebanyak 37 responden $(68,5 \%)$ berdasarkan distribusi umur terlihat rentan usia 26 - 35 tahun dan 35 - 45 tahun memiliki kategori perokok berat tertinggi yaitu masing masing sebanyak 17 responden $(70,8 \%)$. Dari data ditas dapat disimpulkan bahwa rata -rata perokok pria di wilayah Pulau harapan mengkonsumsi rokok lebih dari 15 batang per hari. Hal ini haruslah menjadi perhatian karena dengan konsumsi rokok yang begitu tinggi tentunya memperbesar resiko penyakit yang dapat timbul diakibatkan merokok terutama peyakit gigi dan mulut yang menyertai.

Berdasarkan uji statistik mengenai hubungan klasifikasi perilaku merokok dengan Keadaan jaringan periodontal dilihat dari skor CIPTN pada perokok dengan klasifikasi sedang masalah umum yang paling sering muncul pada jaringan periodontal ialah Karang Gigi pada Sub gingiva yaitu sebanyak 9 responden $(52,9 \%)$ hal yang sama juga terjadi pada perokok dengan klasifikasi berat yaitu sebanyak 27 responden (50\%). Dari uji statistik juga didapatkan adanya hubungan klasifikasi perokok dengan Skor CIPTN jaringan periodontal. Dengan didapatkannya hasil penelitian tersebut dapat dilihat bahwa Karang Gigi pada Sub gingiva merupakan masalah umum yang timbul pada perokok sedang dan berat di Pulau Harapan. Tingginya jumlah perokok pria di wilayah pulau harapan merupakan hal yang harus diantisipasi, penambahan jumlah perokok baru harus dapat dikendalikan dengan pendidikan kesehatan sejak dini. Bahaya rokok bagi kesehatan 
terutama terhadap kesehatan gigi dan mulut harus dapat disosialisasikan sejak dini guna mengurangi derajat keparahan penyakit periodontal.

\section{Kesimpulan}

Berdasarkan hasil penelitian dapat disimpulkan bahwa sebagian besar Pria perokok di Pulau Harapan berada pada rentan usia 26 - 35 Tahun dan 35- 45 tahun dengan klasifikasi terbanyak merupakan prokok berat sebanyak 37 responden (68,5\%), keadaan jaringan periodontal yang terbanyak ialah pada skor 2 CIPTN atau terdapat karang gigi pada sub ginggiva sebanyak 27 responden (50\%), berdasarkan analisis hubungan dapat dilihat adanya hubungan signifikan antara klasifikasi perokok dengan keadaan jaringan periodontal yang dihitung dengan Skor CIPTN.

Dengan didapatkannya hasil penelitian ini diharapkan dapat menjadi bahan pertimbangan bagi dinas kesehatan setempat dan pihak terkait guna pembuatan program yang tepat, efektif dan efisien dalam menghadapi efek samping merokok bagi kesehatan gigi dan mulut dalam rangka menciptakan derajat kesehatan gigi dan mulut yang setinggi tingginya.

\section{Referensi}

[1]. Aji, dkk. (2015). Isolasi Nikotin Dari Puntung Rokok Sebagai Infektisida. Jurnal Teknologi Kimia Unimal. Vol. 4 No. 2

[2]. Alamsyah, dkk. (2012). Hubungan Kebiasaan Merokok Dengan Status Jaringan Periodontal Tukang Becak di Sekitar Kampus USU Medan. Dentika Dental Jurnal. Vol. 17 No. 2

[3]. Alamsyah \& Nopianto. (2017). Determinasi Perilaku Merokok Pada Remaja. Journal Endurance. Vol. 2 No. 1

[4]. Ambarwati, dkk. (2014). Media leaflet, video dan pengetahuan siswa SD tentang bahaya merokok. Jurnal kesehatan masyarakat. Vol. 10 no. 7-13

[5]. Binita, dkk. (2016). Hubungan Persepsi Merokok Dengan Tipe Perilaku Merokok Pada Siswa SMK "X” di Kota Semarang. Jurnal Kesehatan Masyarakat. Vol. 4 No. 5

[6]. Hongini, Siti Yundali. (2012). Kesehatan Gigi dan Mulut. Bandung : Pustaka Reka Cipta

[7]. Kemenkes. (2018). Riskesdas Kesehatan Gigi dan Mulut. (Online). https://depkes.go.id/resources/download/infoterkini/materi rakopop 2018/hasil\%20Riskes das\%202018.pdf. Diakses pada 29 Oktober 2019

[8]. Kusuma, A.R.P. (2010). Pengaruh merokok terhadap kesehatan gigi dan mulut. Jurnal cermin dunia kedokteran. No. 34 Vol. 365

[9]. Nelis, dkk, (2015). Hubungan Kebiasaan Merokok Dengan Status Kesehatan Jaringan Periodontal. Dental Journal. Vol. 4 Hal. 23-25

[10]. Novitasari, dkk. (2018). Gambaran Tingkat Pengetahuan siswa SMA Negeri Manado Tentang Dampak Merokok Bagi Kesehatan Gigi dan Mulut. Jurnal e-Gigi. Vol. 2 No. 2

[11]. Notoatmodjo. (2018). Metodologi Penelitian Kesehatan. Jakarta : Rineka Cipta

[12]. Nujanah, dkk. (2014). Gangguan Fungsi Paru dan Kadar Continine Pada Urin Karyawan yang Terpapar Asap Rokok Orang Lain. Jurnal Kesehatan Masyarakat. Vol. 10 Hal. 1

[13]. Putri, M. H. (2015). Ilmu Pencegahan Penyakit Jaringan Keras Dan Jaringan Pendukung Gigi. Jakarta : EGC

[14]. Saptorini \& Kusuma. (2013). Poket Periodontal Pada Buruh Perokok. Stomatognatic (J. K. G Unej). Vol. 10 Hal. $67-70$

[15]. Sujarweni, Wiratna. V. (2014). Metodologi Penelitian Keperawatan. Yogyakarta : Gava Media 
[16]. Tyas, dkk. (2016). Gambaran Penyakit Periodontal Pada Usia Dewasa Muda (15 - 30 tahun) di Puskesmas Srondol Kota Semarang. Jurnal Kesehatan Masyarakat. Vol. 4 No. 4

[17]. Tambunan, dkk. (2015). Gambaran Penyakit Periodontal pada Penderita Diabetes Millitus di Rumah Sakit Umum Pusat. Jurnal e-gigi. Vol. 3 No. 2

[18]. WHO, 2015. Global Youth Tobacco Survey (GYTS): Indonesia report 2014, Availableat:http://www.searo.who.int/tobacco/documents/ino_gyts_report_2014.pdf.

[19]. Zubardiah, Lies. (2011). Jaringan Periodonsium Anatomis, Klinis, Dan Histologis. Jakarta : EGC 